\title{
Analysis of the ABO and RH (D) Blood Groups Among Third Year Integrated Science Education Students of the University of Education, Winneba
}

\author{
C. K. Koomson (Corresponding Author)
}

Department of Integrated Science Education, University of Education, Winneba, P.O. Box 25, Winneba, Central Region, Ghana

C. Owusu-Fordjour

Department of Science Education, University of Education, Winneba, P.O. Box 25, Winneba, Central Region, Ghana. E-mail: charleskoomson@yahoo.co.uk

\section{Afari-Baidoo}

Department of Biology Education, University of Education, Winneba, P.O. Box 25, Winneba, Central Region, Ghana

\section{A. Biritwum}

Department of Science Education, University of Education, Winneba, P.O. Box 25, Winneba, Central Region, Ghana

Received: Apr. 15, 2020 Accepted: May 14, 2020

doi:10.5296/jbls.v11i2.16853 URL: https://doi.org/10.5296/jbls.v11i2.16853

\begin{abstract}
The objective of this study is to get an information about the distribution of $\mathrm{ABO}$ and Rhesus blood group, among the Education students of the University of Education, Winneba. Also it is a need for routine screening for hemolysin among blood group $\mathrm{O}$, if found to be high, as well as to institute donor registry for Rhesus negative blood group, if found to be low. Records of ABO and Rhesus blood grouped results of students were screened in November 2019. Data were analyzed by the use of the software Epi info, version 5.3.4. Descriptive statistics were used to compute percentages and averages. Results are presented in tables and
\end{abstract}


charts, and expressed as percentages/ proportions, and means. One hundred and sixty-six results were obtained, made up of 132 males and 34 females. Among the population studied, blood group O had the highest frequency, 93 (56\%), followed by blood group A, 39 (23.5\%), then B, $29(17.5 \%)$, while AB had the least frequency, 5 (3\%). Most of students were found to be Rhesus positive (92.2\%) while Rhesus negative were only $7.8 \%$. Blood group $\mathrm{O}$ was found to be highest among the study population followed by A, B and AB in that order. Most of the students were found to be Rhesus positive while only a few were Rhesus negative. Routine screening for hemolysin among blood group $\mathrm{O}$ and institution of donor registry is recommended.

Keywords: ABO blood groups, rhesus blood groups, university students

\section{Introduction}

The ABO blood group was the first human blood group discovered in 1901 by Landsteiner followed by Rh blood group in 1941 (Garratty, et al., 2000; Rahman and Lodhi, 2004). Currently more than 30 blood groups are described by the International Society of Blood Transfusion of which only ABO and Rh blood groups remain clinically important (Giri et al., 2011; ISBT, 2008). The ABO blood group system is governed by a single gene located on chromosome 9 with three alleles (IA, IB and IO) (Zahid et al., 2016).

The IA and IB alleles are co-dominant, but both of them are dominant over the recessive allele IO in intra-allelic interaction in diploid condition (Murphy et al., 2003). The ABO system is determined by the presence of red blood cell antigens, an antigen A (group A), B antigen (group B), or both antigens (group AB), or neither of the antigens (group O), which classifies all human blood in one of four groups (phenotypes) A, B, AB, O (Zahid et al., 2016) with six genotypes, that is $\mathrm{OO}$ (type O), OA (type A), OB (type B), AA (type A), BB (type B), AB (type AB (Khalid et al., 2013). Rhesus blood group system (Rh) is the second most important blood group system due to hemolytic disease of newborn. It is determined by a gene located on the short arm of chromosome 1 (Murphy et al., 2003) with two alleles (D and d). Individuals who have the $\mathrm{D}$ antigen on their red cells are known as Rhesus-positive $(\mathrm{Rh}+)$ (DD or Dd genotype) while those without antigen D (dd genotype) in their red blood cells are Rh- (Knowles \& Poole, 2002). Antibodies to D can cause transfusion reactions.

The frequency of the $\mathrm{ABO}$ and $\mathrm{Rh}$ blood groups vary worldwide and may not be found in equal numbers in various populations. Among African-Americans the distribution of $\mathrm{ABO}$ blood group, type O, 46\%; type A, 27\%; type B, 20\%; and type AB, 7\%. Among Caucasians in the United States, the distribution of type $\mathrm{O}$ is $47 \%$; type $\mathrm{A}, 41 \%$; type $\mathrm{B}, 9 \%$; and type $\mathrm{AB}$ 3\%. Among Western Europeans type O, 46\%; type A, 42\%; type B, 9\%; and type AB, 3\% (Pramanik, 2000). In African American, Rhesus (D) negative is approximately 7\% and Rhesus (D) positive is 93\%. In other Europeans, Rhesus (D) negative is about $16 \%$ and Rhesus (D) positive is $84 \%$. In African descent, Rhesus (D) negative is less than $1 \%$ and Rhesus (D) positive is over 99\% (Bamidele et al., 2013).

The success of human blood transfusion requires compatibility for the two major blood group antigen systems and on the ability of agglutinins of both blood groups to cause haemolytic 
transfusion reaction and haemolytic disease of the fetus and newborn (Knowles \& Poole, 2002; Murphy et al., 2003). Blood transfusion is a life-saving procedure, but can cause acute and delayed complications. Complications of blood transfusions with wrongly labeled blood groups may be mild or can be life-threatening.

As blood group determination is important in clinical practice, it was desirable to find out the prevalence of different blood groups among students of the Integrated Science Education of the University of Education, Winneba. The present study was therefore carried out to during a class practical lesson to determine the distribution of ABO and Rhesus blood groups among students of the department. The aim is to have information about the distribution pattern of these blood groups which may help to improve blood transfusion services, by routine screening for hemolysin among blood group $\mathrm{O}$, if found to be high, as well as institution of donor registry for Rhesus negative blood group, if found to be low. This will help to prevent hemolytic transfusion reactions and death because of hemolytic disease of the fetus and newborn as well as to make for easy accessibility to rhesus negative blood for transfusion especially in cases of emergency.

\section{Materials and Methods}

\subsection{Study Site and Sample of Population}

This study was carried out at the University of Education, Winneba, Department of Integrated Science Education Laboratory, in November 2019. A total of 166 students of the Integrated Science Education Department took part in the practical class. The blood collections were taken from the students. Out of 166 students were 132 males and 34 females.

\subsection{ABO and Rh-blood Group's Tests}

Blood samples from each student was taken by Scrub" with "scrubbing with a piece of cotton saturated with $70 \%$ alcohol and pierce it with a sterile disposable lancet and was placed a small drop of blood on a three clean white glass microscope slide on which a few drops of antiserum for blood group A and B was applied following Bhasin \& Chahal (1996). Commercially available standard antiserum A, antiserum B and antiserum D were used for the study. Blood grouping was done by commercial reagent kit manufactured by SPINREACT, S.A.U.-Ctra. Santa Coloma, 7E-17176 SANT ESTEVE DE BAS-(Gerona) Spain and obtained from the Otu Memorial Hospital in Winneba. Blood was treated with anti-A, anti-B and anti-D antiserum on separate glass slides, marked as A, B and D and were mixed with separate sterilized applicator sticks. The mixture was observed for agglutination. The blood group was determined based on agglutination with the corresponding antiserum. If agglutination was present in the blood drop A, then it belongs to A blood group, agglutination in blood drop B, B group, agglutination in both A and B blood drops, AB group and if no agglutination in both $\mathrm{A}$ and $\mathrm{B}$ drops, then $\mathrm{O}$ group. Similarly, agglutination in blood drop D was considered as Rh+ and no agglutination Rh- (Avent \& Reid, 2009). Therefore, the results were recorded as $\mathrm{A}+, \mathrm{B}+, \mathrm{AB}+, \mathrm{O}+$ and $\mathrm{A}-, \mathrm{B}-, \mathrm{AB}-$ and $\mathrm{O}-$.

Descriptive statistics were used to compute percentages and averages. Results were presented in tables and charts and expressed as percentages/proportions, means and standard deviation. 


\section{Macrothink}

\section{Ethical clearance}

The study protocol was reviewed and approved by the Departmental Board ethical clearance committee. Before data collection, an informed consent was obtained from the students and collected data were kept confidential.

\section{Results}

One hundred and sixty-six results were obtained, made up of 132 males and 34 females. Among the population studied, blood group O had the highest frequency, 93 (56\%), followed by blood group A, 39 (23.5\%), then B, 29 (17.5\%), while AB had the least frequency, 5 (3\%) (Figure 1). According to the rhesus system, most of the students were found to be Rhesus positive with frequency of 154 (92.2\%) while Rhesus negative was 12 (7.8\%) (Figure 2).

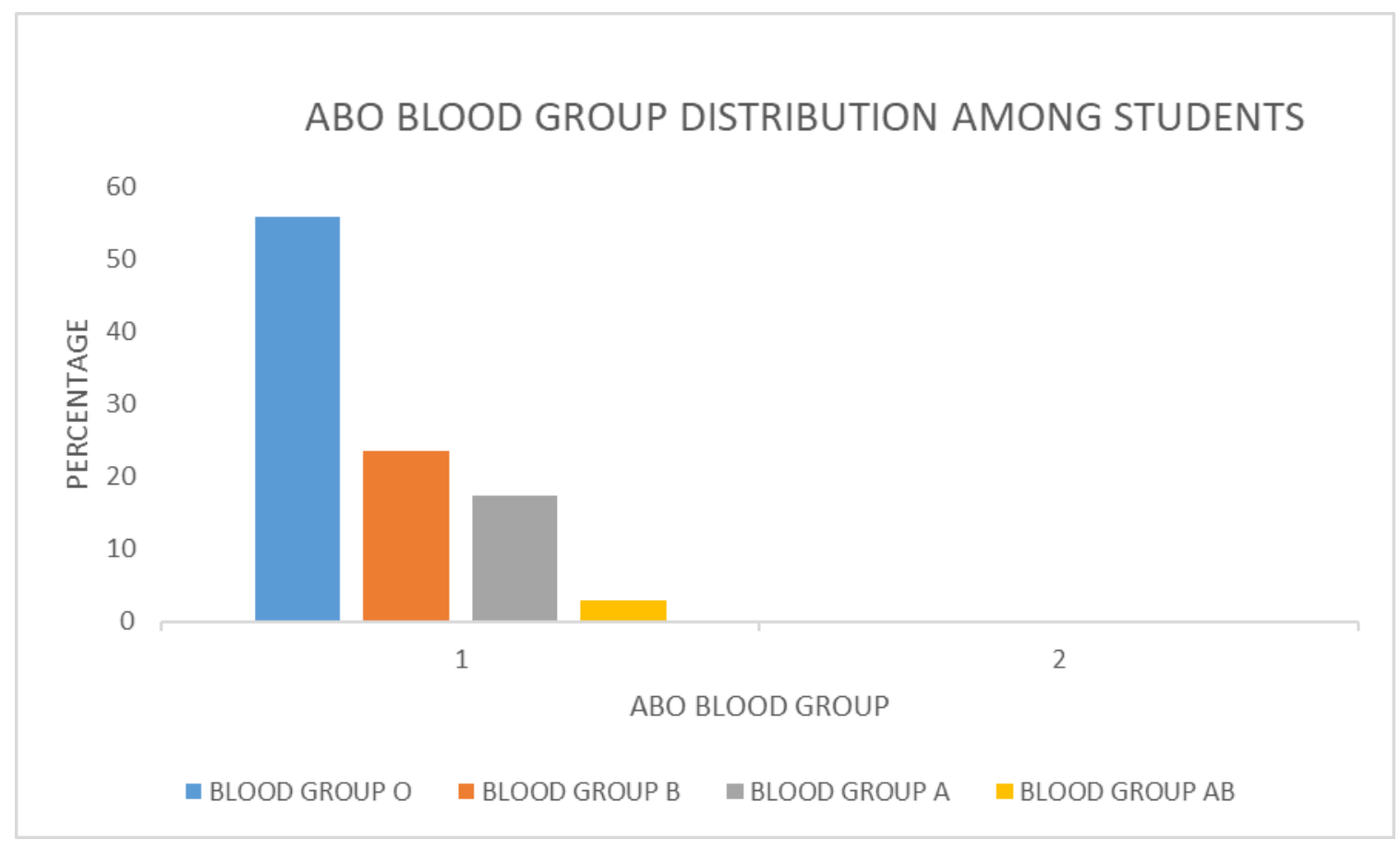

Figure 1. ABO blood group distribution pattern of the students 


\section{Rhesus blood group distribution pattern among the students}

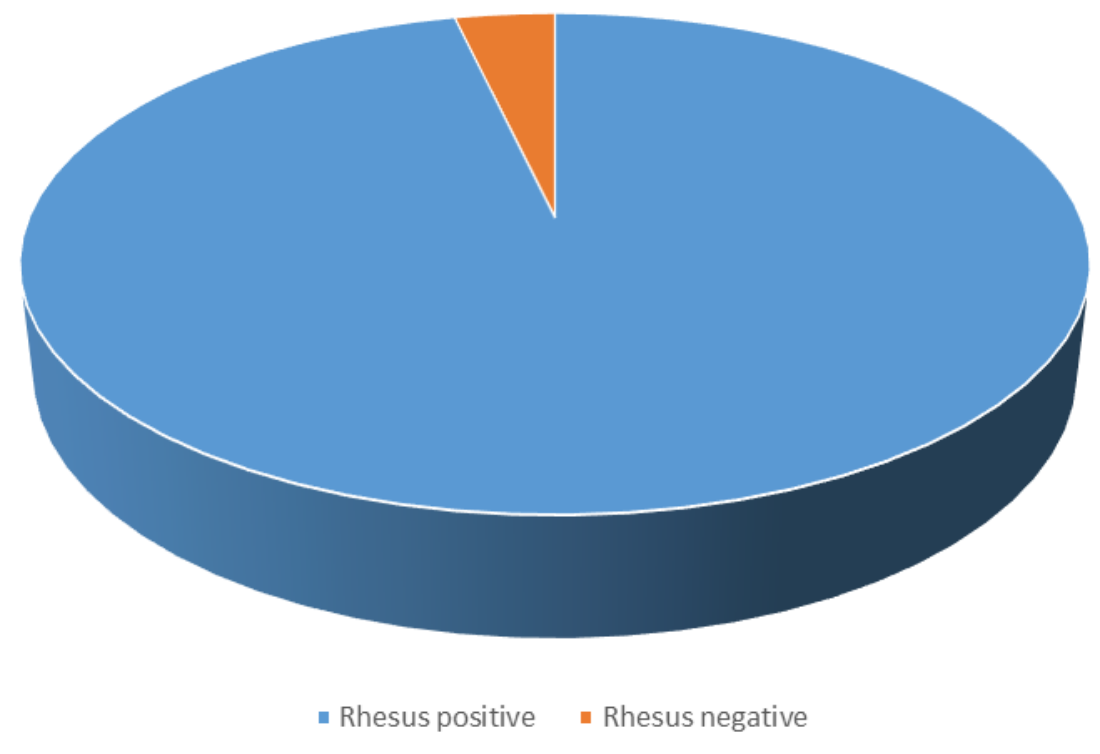

Figure 2. Rhesus blood group distribution pattern among the students

Among the male students, blood group $\mathrm{O}$ was the highest with a frequency of $72(54.3 \%)$, followed by blood group A with a frequency of 38 (28.8\%). Frequency of blood group B and $\mathrm{AB}$ were 19 (14.8\%) and 3 (2.3\%) respectively. Likewise, among the female students, blood group $\mathrm{O}$ had the highest frequency, 19 (55.9\%), followed by blood group A with a frequency of $8(23.5 \%)$, then blood group B, 5 (14.7\%), while blood group AB was the least, $2(5.9 \%)$ (Table 1). Majority of the male and female students were found to have rhesus positive blood group, $126(95.5 \%)$ and $32(94.1 \%)$ respectively (Table 2$)$. With regards to rhesus blood group system among the population studied, blood group $\mathrm{O}+$ was the most common with frequency of $88(53 \%)$, followed by A+ with frequency of $36(21.7 \%)$, then $\mathrm{B}+25(15.1 \%)$ and $\mathrm{AB}+4(2.4 \%)$, whereas among the rhesus negative students, blood group $\mathrm{O}-$ was the most frequent $5(3.0 \%)$, blood group A- was 3(1.8\%), B- was 4 (2.4\%) while blood group AB- was $1(0.6 \%)$, as shown in Table 3. 
Table 1. ABO blood group distribution according to gender

\begin{tabular}{c|c|c|l|c}
\hline \multirow{2}{*}{ ABO Blood Group } & \multicolumn{2}{|c|}{ Males } & \multicolumn{2}{l}{ Females } \\
\cline { 2 - 5 } & Frequency & Percentage & Frequency & Percentage \\
\hline O & 72 & 54.5 & 19 & 55.9 \\
A & 38 & 28.8 & 8 & 23.5 \\
B & 19 & 14.4 & 5 & 14.7 \\
AB & 3 & 2.3 & 2 & 5.9 \\
Total & 132 & 100 & 34 & 100 \\
\hline
\end{tabular}

Table 2. Rhesus blood group according to gender

\begin{tabular}{c|c|c|c|c}
\hline Rhesus Blood Group & \multicolumn{2}{|c|}{ Males } & \multicolumn{2}{l}{ Females } \\
\hline & Frequency & Percentage & Frequency & Percentage \\
\hline Rhesus positive & 126 & 95.5 & 32 & 94.1 \\
\hline Rhesus negative & 6 & 4.5 & 2 & 5.9 \\
\hline Total & 132 & 100 & 34 & 100 \\
\hline
\end{tabular}

Table 3. Distribution of ABO and Rhesus blood group systems among the students

\begin{tabular}{ccc}
\hline Blood Group & Frequency & Percentage \\
\hline O+ & 88 & 53.0 \\
A+ & 36 & 21.7 \\
B+ & 25 & 15.1 \\
AB+ & 4 & 2.4 \\
O- & 5 & 3.0 \\
A- & 2 & 1.8 \\
B- & 4 & 2.4 \\
AB- & 1 & 0.6 \\
Total & 166 & 100 \\
\hline
\end{tabular}




\section{Discussion}

The study of blood groups is fundamental in the clinical practice due to the inherent relationship in transfusion medicine and organ transplants (Roback et al., 2011). In blood banks, it is challenging to get enough blood units, especially for the less frequent blood types (Fufa \& Debelo, 2019). Thus, it is necessary to implement effective programs among health institutions to get specific blood types and products according to their geographic distribution. To meet this need it is important to know the distribution of ABO and $\mathrm{Rh}$ (D) blood groups in several areas of a country (Canizalez-Román et al., 2018).

The frequencies of $\mathrm{ABO}$ and $\mathrm{Rh}$ blood groups vary worldwide and are not found in equal numbers even among ethnic groups of the same country. Many studies have shown that blood group $\mathrm{O}$ is the most common while $\mathrm{AB}$ is the least common in different ethnic groups (Nwauche \& Ejele, 2004). The result of the current study revealed that the frequencies of the blood group distribution was in the order $\mathrm{O}>\mathrm{A}>\mathrm{B}>\mathrm{AB}$. Accordingly, type $\mathrm{O}$ was the highest (56\%), A (23.5\%), B (17.5\%) and $\mathrm{AB}(3 \%)$. With regard to Rh factor, most $(96.4 \%)$ of the participants were $\mathrm{Rh}+$ while only $3.6 \%$ were $\mathrm{Rh}$ - which is in agreement with most studies conducted in different parts of the world, including Ghana, though the figures may vary significantly.

Blood group $\mathrm{O}$ was initially regarded as a universal donor and so can be given to anybody with any other blood group apart from group O. It has been documented that some blood group $\mathrm{O}$ individuals have high titer of hemolysin an anti-A and anti-B antibodies in their plasma and so can cause hemolytic transfusion reaction and death when such blood group $\mathrm{O}$ is transfused to anybody with any other blood type apart from group O (Olawumi \& Olatunji 2001). Since majority of the study population have blood group O, there may be need for routine screening for hemolysin among blood group O individuals (Ugwu, 2016).

This study also found that among the both male and female students, blood group $\mathrm{O}$ has the highest frequency, followed by blood group $\mathrm{A}, \mathrm{B}$ and $\mathrm{AB}$ in that order. This corroborates with findings of previous studies that reported similar pattern of $\mathrm{ABO}$ blood group distribution among both sexes (Enosolease \& Bazuaye, 2008). However, some other studies reported blood group A to be the most frequent among males, while blood group B has the highest frequency among females (Ghobadian, 2014, Rai \& Kumar, 2011). Most of the male and female students were found to have rhesus positive blood group as also reported by previous studies (Nwuche \& Ejele, 2004; Enosolease \& Bazuaye, 2008). This shows that inheritance of ABO and rhesus blood groups are not sex-linked (Edgren et al 2010).

The higher distribution of blood type $\mathrm{O}$ recorded in this study has advantage to the students who live in and around Winneba where malaria is prevalent. Lemu et al. (2017) reported that there is a hypothesis that the frequency of group ' $O$ ' is higher than non-' $O$ ' phenotype in malaria endemic areas. It appears that the students with blood type ' $O$ ' better survived severe malaria. On the other hand, both Rh-negative and ' $\mathrm{O}$ ' phenotype might have encouraged malaria transmission in the area as asymptomatic carriers prevailed probably because of their resistance to malarial disease showing the beneficial effects of the phenotype (Fufa \& Debelo, 2019). Thus, dominance of $\mathrm{O}$ group could be protective against malaria because studies have 
shown that the erythrocytes of an individual with blood type $\mathrm{O}$ might not be suitable for rosette formation by Plasmodium falciparum (Fufa \& Debelo, 2019). Besides, the higher prevalence of type ' $\mathrm{O}$ ' blood has its advantage which may include emergency blood transfusion as blood group $\mathrm{O}$ is a universal donor (lack both $\mathrm{A}$ and $\mathrm{B}$ antigen) hence it is readily available. This can also be seen as good input for blood bank services for effective management of blood and safe blood transfusion services (Lemu et al., 2017).

The results of this study revealed that the frequency of Rh- was very low (7.8\%) and the scenario may imply the shortage and difficulty of getting it when required from blood banks and to meet patient's need. In line with this, Lemu et al. (2017) reported that Rh- blood group is rare in many populations which implies that it is scarcely available in blood banks and thus populations in which Rh-negative group is more common may be approached, individuals are encouraged and convinced to donate blood to make this blood group more available in blood banks.

\section{Conclusion}

In the current study the pattern of distribution of the $\mathrm{ABO}$ blood groups was $\mathrm{O}>\mathrm{A}>\mathrm{B}>\mathrm{AB}$ and most $(92.2 \%)$ of the participants were $\mathrm{Rh}+\mathrm{O}+$ also being the most frequent $(53 \%)$. The frequency of Rh- blood group among the study population was very low which indicates the scarcity of people with the blood type and difficulty of getting it when it is needed. Therefore, the outcome of this study could be used as baseline information for the effective management of a Blood Bank inventory in and around the Winneba Township.

\section{References}

Avent, N. D., \& Reid, M. E. (2000). The Rh blood group system: a review. Blood, 95(2), 375-87. https://doi.org/10.1182/blood.V95.2.375

Bamidele, O., Arokoyo, D. S., \& Akinbola, A. O. (2013). Distribution of ABO and rhesus blood groups among medical students in Bowen University, Iwo, Nigeria. Annals of Biological Research, 4(11), 1-6.

Bhasin, M. K., \& Chahal, S. M. (1996). Immunology a short course.3rd ed. Wiley`s liss New York. P 484. https://doi.org/10.5897/IJSTER

Canizalez-Román, A., Campos-Romero, A., Castro-Sánchez, J. A., LópezMartínez, M. A., \& Andrade-Muñoz, F. J. (2018). Blood Groups Distribution and Gene Diversity of the ABO and $\mathrm{Rh}$ (D) Loci in the Mexican Population. BioMed Research International. https://doi.org/10.1155/2018/1925619

Enosolease, M. E., \& Bazuaye, G. N. (2008). Distribution of ABO and Rh-D blood groups in the Benin area of Niger-Delta: implication for regional blood transfusion. Asian $J$ Transfusion Sci., 2(1), 3-5. https://doi.org/10.4103/0973-6247.39502

Fufa, A. W., \& Debalo, D. G. (2019). Distribution of ABO and Rh (D) blood groups among students attending secondary and preparatory schools in Bote town, Oromia national regional 
state, Ethiopia, International Journal of Science and Technology Educational Research, 10(1), 1-8. https://doi.org/10.5897/IJSTER2019.0448

Garratty, G., Dzik, W., Issitt, P. D., Lublin, D. M., Reid, M. E., \& Zelinski, T. (2000). Terminology for blood group antigens and genes - historical origins and guidelines in the new millennium, Transfusion, 40(4), 477-489. https://doi.org/10.1046/j.1537-2995.2000.40040477.x

Ghobadian, Z., Sayemiri, K., Zeinaii, M., \& Saijjadi, S. M. (2014). Disribution of ABO and $\mathrm{Rh}$ blood groups in a major ethnic group of the West Iran, the Kurdish population. Asian Journal of Medical Sciences, 5(3), 26-29. https://doi.org/10.3126/ajms.v5i3.9151

Giri, P. A., Yadav, S., Parhar G. S., \& Phalke, D. B. (2011). Frequency of ABO and rhesus blood groups: a study from a rural tertiary care teaching hospital in India, International Journal of Biological and Medical Research, 2(4), 988-990. BioMedSciDirect Publications IJBMR ISSN: 0976:6685.

ISBT, (2008). Table of Blood Group Systems, International Society of Blood Transfusion (ISBT). https://doi.org/10.1111/j.1751-2824.2008.00188.

Khalid, M., Aslam, N., Aslam, M., \& Ahmad, R. (2013). Distribution of ABO and Rh (D) blood groups among blood donors in district Mardan, Pakistan. Journal of Saidu Medical College, 3(2), 318-322. https://doi.org/10.1177/004947550103100121

Knowles, S., \& Poole, G. (2002). Human blood group systems. In: Murphy MF, Pamphilon DH, editors. Practical Transfusion Medicine. 1st ed. London, UK: Blackwell Science, 24-31.

Lemu, G., Arega, T., Berhanu, E., \& Hassen, M. (2017). High rhesus (Rh(D)) negative frequency and ethnic-group based $\mathrm{ABO}$ blood group distribution in Ethiopia. BMC Research Notes, 10(1), 330. https://doi.org/10.1186/s13104-017-2644-3

Murphy, W. J., Fronicke, L., O'Brien, S. J., \& Stanyon, R. (2003). The Origin of Human Chromosome 1 and Its Homologs in Placental Mammals". Genome Research, 13(8), 1880-1888. https://doi.org/10.1101/gr.1022303

Nwauche, C. A., \& Ejele, O. A. (2004). ABO and rhesus antigens in a cosmopolitan Nigeria population. Nigerian Journal of Medicine, 13(3), 263-266. PMID: 15532229.

Olawumi, H. O., \& Olatunji, P. O. (2001). Prevalence and titer of alpha and beta hemolysins in blood group $\mathrm{O}$ donors in Ilorin. African Journal of Medicine and Medical Sciences, 30(4), 319-321. https://doi.org/10.4172/2572-9462.1000104

Pramanik, T. (2000). Distribution of ABO and Rh blood groups in Nepalese students: A report. Eastern Mediterranean Health Journal, 6(1), 156-158. https://doi.org/10.3126/jmcjms.v1i2.9263

Rahman, M., \& Lodhi, Y. R. (2004) Frequency of ABO and Rhesus blood groups in blood donors in Punjab, Pakistan Journal of Medical Sciences, 20(4), 315-318. https://doi.org/10.12669/pjms.314.6640 


\section{Macrothink}

Rai, V., \& Kumar, P. (2011). Genetic analysis of ABO and Rh blood groups in Backward Caste Population of Uttar Pradesh, India. Nat. Sci. Biol., 3(3), 7-14. https://doi.org/10.15835/nsb336073

Roback, J. D., Grossman, B. J., Harris, T., \& Hillyer, C. D. (2011). American Association of Blood Banks: Technical Manual, American Association of Blood Banks.

Ugwu, N. I. (2015). Pattern of ABO and Rhesus blood group distribution among students of Ebonyi State University, Abakaliki, South Eastern Nigeria, Asian Journal of Medical Sciences, 7(1), 101-104. https://doi.org/10.3126/ajms.v7i1.12716

Zahid, H., Yahyaoui, A., Uwingabiye, J., El Khazraji, A., El Hadef, R., \& Messaoudi, N. (2016). Phenotypic and allelic distribution of ABO and Rh-D blood Groups in Blood Transfusion Center of Avicenna Military Hospital, Marrakesh, Morocco. International Journal of Medicine and Health Research, 2(1), 1-9.

\section{Copyright Disclaimer}

Copyright for this article is retained by the author(s), with first publication rights granted to the journal.

This is an open-access article distributed under the terms and conditions of the Creative Commons Attribution license (http://creativecommons.org/licenses/by/4.0/). 